\title{
Protein profiles and total antioxidant capacity of water soluble and insoluble protein fractions of white cow cheese at different stage of ripening
}

doi: $10.15567 / \mathrm{mljekarstvo.2016.0303}$

\author{
Miroljub Baraći ${ }^{*}$, Milenko Smiljanićz Sladjana Žilić3, Mirjana Pešićc \\ Sladjana Stanojević ${ }^{1}$, Milena Vasić ${ }^{1}$, Tanja Vučić ${ }^{1}$ \\ ${ }^{1}$ University of Belgrade, Faculty of Agriculture, Nemanjina 6, Belgrade, Serbia \\ ${ }^{2}$ Faculty of Technology, Zvornik, Karakaj bb, Bosnia and Herzegovina \\ ${ }^{3}$ Maize Research Institute, Slobodana Bajica 1, Belgrade, Serbia
}

Received - Prispjelo: 30.11.2015.

Accepted - Prihvaćeno: 16.05.2016.

\begin{abstract}
This research is focused on proteolysis and total antioxidant capacity of proteins of white brined cheese prepared from overheated $\left(90^{\circ} \mathrm{C}, 10\right.$ minutes) cow milk. White brined cow cheese of overheated milk went through specific proteolytic changes during ripening that were result of high level of whey proteins incorporated into the gel matrix. Specificity was reflected through the relatively low level of soluble nitrogen fractions, the intensive and continual decrease of $\alpha_{\mathrm{s}}$-caseins up to $15.42 \%$ of initial content, slow degradation of $\beta$-casein throughout the whole ripening period and high level of proteolytic products tightly bounded into gel matrix. Strong negative correlations $(-0.97,-0.98$ and $-0.91 ; p<0.05)$ between ripening time and resudual $\alpha_{s}$-caseins, $\beta$-casein and low molecular weight products were observed. Proteolysis also affected the total antioxidant capacity of both water soluble and water insoluble nitrogen fractions, but to different extents and with different trends. Total antioxidant capacity of water insoluble fraction increased slowly during the whole ripening period, wherease significant improvement of total antioxidant capacity of water soluble fraction started after 30 days of ripening. These findings could be useful for better understanding and control of the white brined cow cheese production.
\end{abstract}

Key words: overheating, white cow cheese, proteolysis, antioxidant capacity

\section{Introduction}

White brined cheese is the most consumed type of cheese in South-East European countries and is most commonly made from heated cow milk. Specificity of this type of cheese is that ripening occurs in brine, usually for one or two months. The most important biochemical process that occurs during ripening of cheese is proteolysis. Several factors including type and characteristics of milk, heating conditions of milk, curd processing and ripening conditions have significant influence on the level of proteolysis and thus on cheese properties (Maćej et al., 2007).
It is known that heating alters the coagulation properties of milk and interferes in ripening of cheese due to inactivation of endogenous enzymes, destruction of the natural microflora and alteration of the accessibility of the substrates by exogenous hydrolytic enzymes (Benfeldt and Sorensen, 2001). The influence of heating on proteolysis is determined by the level of temperature and duration of heating. It is well known that heating of milk above $70^{\circ} \mathrm{C}$ induces denaturation of proteins, their re-assotiation into the so-called whey protein- casein complexes (WP-CN) mainly throught disulphide 
and hydrophobic interactions (Maćej et al., 2007; Considine et al., 2007). WP-CN complexes could be formed between serum proteins and caseins, mostly between $\beta-\lg , \alpha-1 \mathrm{la}$ and $\kappa-\mathrm{CN}$ (Considine et al., 2007). These complexes could form molecules of major whey proteins alone, but also other whey proteins and caseins (a part of $\alpha_{s}$ - and $\beta-\mathrm{CN}$ ) could be incorporated in them (Chevalier et al., 2009). A part of heat-induced WP-CN complexes are distributed on casein micelles (e.g. micellar complexes) and are consequently involved into the cheese matrix, whereas a part of so-colled soluble complexes are distributed into the whey. Their formation, composition and distribution are influenced by several factors such as milk type, milk composition, $\mathrm{pH}$ and heating conditions (Vasbinder and de Kruif, 2003; Pesic et al., 2012, 2014). Incorporation of whey proteins into gel matrix increased yield and nutritive value of cheese. Since whey proteins are more resistant to proteolysis than caseins (Trujillo et al., 2002), their incorporation into the cheese matrix might affect proteolysis.

Several studies carried out in the past 15 years clearly showed that cheeses and the other fermented milk-based products contained a large number of bioactive proteins and peptides including those with ACE-inhibitor, antimicrobial, immunostimulatory and antioxidant activity (Möller et al., 2008; Corrêa et al., 2011; Pattom and Hongsprabhas, 2013). According to the current knowledge, a large part of antioxidant proteins and peptides originate from milk itself but most of them were formed during cheese production. Intact caseins were shown to possess antioxidant activity (Power et al., 2013). The proposed mechanism of antioxidant activity of caseins was the quenching of free radicals by the oxidation of amino acids in caseins. Parella et al. (2012) recognized mild heat treatment of milk as a stage of cheese processing during which antioxidant peptides could be released. However, cheese ripening and proteolysis as the most complex process that occurs during ripening was identified as the major stage of their formation (Korhonen and Pihlanto, 2003). Antioxidant peptides are mostly derived from caseins due to the action of peptidases released from both, starter and non-starter lactic acid bacteria (Rival et al., 2001; Pattom and Hongsprabhas, 2013; Kumar et al., 2013). The level of their formation depends on ripening conditions and ripening stage (Gupta et al., 2009). Besides caseins, whey proteins and their proteolytic products also exert antioxidant activity (Zulueta et al., 2009; Power et al., 2013; Çekiç et al., 2015). Thus, it can be assumed that incorporation of whey proteins into cheese matrix could considerably improve antioxidant capacity and, in general, functionality of cheese.

In current literature numerous data related to proteolysis of different cheese varieties exist (Guven and Kuraca, 2001; Moatsou et al., 2001; Alichanidis and Polichroniadoy, 2008; Maćej et al., 2007; Barać et al., 2013; Smiljanić et al., 2014) whereas several are related to their antioxidant properties (Korhonen and Pihlanto, 2006; Gupta et al., 2009). However, proteolysis of white brined cheeses prepared from overheated milk has not been sufficiently investigated. So far the antioxidant properties of proteins of white brined cheese, especially those prepared from overheated cow milk were not reported. Furthermore, the object of the most of previosly reported studies was the water soluble protein fraction of cheese. Since several different factors, including amino acid composition, amino acid position in the protein sequence, three-dimensional structure and molecular weight of proteins, their hydrophobicity and the degree of formation of Maillard products (Diaz et al., 2003; Elias et al., 2008; Yates et al., 2010; Žilić et al., 2012) may influence antioxidant properties of proteins, it could be assumed that water insoluble fraction which represents majority of cheese proteins also exibits antioxidant capacity. Thus, the aims of this study were to characterize proteolysis of white brined cheese prepared from overheated cow milk, to determine the antioxidant capacity of water soluble and insoluble protein fractions of ripened cheese induced by proteolysis and to correlate them. These findings could provide a more realistic view of antioxidant properties of white cheese and be helpful for better understanding and production of cheeses with improved functionality. For this purpose, white cow cheese was prepared from overheated milk (at $90{ }^{\circ} \mathrm{C}$ for $10 \mathrm{~min}$ ) and ripened for 50 days. During this period optimum maturity of this type of cheese was reached (Barac et al., 2013; Smiljanić et al., 2014). 


\section{Material and methods}

\section{Cheese making}

White cheese was prepared from bovine milk according to procedure for traditional starter-free white cheeses. Fresh milk (10 L) was heated at $90{ }^{\circ} \mathrm{C}$ for $10 \mathrm{~min}$, cooled during one hour and tempered at $35{ }^{\circ} \mathrm{C}$ for $30 \mathrm{~min}$. After that, $200 \mathrm{mg}$ of $\mathrm{CaCl}_{2}$ and $90 \mathrm{mg}$ of chymosin per liter of milk was added. Milk was coagulated within $40 \mathrm{~min}$ at $32-33{ }^{\circ} \mathrm{C}$. Once curdling was completed, the cheese mass was carefully transferred from cheese vats into the mould. After about $2 \mathrm{~h}$ of draining without pressing, the cheese curd was cut into pieces of $10 \times 10 \times 3 \mathrm{~cm}$ and dry salted with $3.0 \% \mathrm{NaCl}$. The next day, cheese was placed into plastic cans and covered with brine ( $8 \%$ solution of $\mathrm{NaCl}$ ). Cheese was ripened during 50 days at $13{ }^{\circ} \mathrm{C}$. Every 10 days cheese was sampled and frozen. The process of cheese making was performed in a duplicate.

\section{Physico-chemical analyses of milk and cheese}

Basic composition of milk was determined using following methods: total protein ( $\mathrm{TN} \times$ 6.38), (AOAC, 1999); dry matter (IDF, 1982) and fat (Ardö and Polychroniadou, 1999). The pH was measured with a $\mathrm{pH}$ meter (Consort, Belgium). For cheese samples characterisation the following parameters were used: total nitrogen content $(\mathrm{TN})$ was determined according to Kjeldahl method (AOAC, 1999) and expressed as total protein in dry matter (TP/DM), dry matter content (IDF, 1982), fat content in dry matter (Ardö and Polychroniadou, 1999), $\mathrm{NaCl}$ content (AOAC, 1999). The $\mathrm{pH}$ of cheeses was measured using a $\mathrm{pH}$ meter (Consort, Belgium) in a slurry prepared by dispersing $5 \mathrm{~g}$ of grated cheese in $10 \mathrm{~mL}$ of deionised water. $\mathrm{NaCl}$ content was measured accoding to AOAC method (1999).

\section{Assessment of proteolysis}

Proteolysis of white brined cheese was followed by: TP/DM, water soluble nitrogen content (WSN), nitrogen soluble in $12 \%$ TCA (TCA-SN) and in $5 \%$ PTA (PTA-SN). WSNs of the cheeses were prepared according to the method of Kuchroo and Fox (1982). TCA-SN and PTA-SN were prepared from water soluble fraction. All of these parameters were determined by the Kjeldahl method (AOAC, 1999) and expressed in dry matter. All determinations were made in triplicate.
Proteolysis was also monitored by SDS-PAGE electroforesis of Tris- $\mathrm{HCl}$ extracts, water soluble, water-insoluble fractions and $\mathrm{pH}$ 4.6-soluble fraction, according to the method of Fling and Gregerson (1986). Tris- $\mathrm{HCl}$ extracts of cheeses were prepared and analysed as previously described (Barac et al., 2013; Smiljanic et al., 2014). Water soluble and water insoluble proteins of cheese were separated according to method of Kuchroo and Fox (1982); $1 \mathrm{~mL}$ of water soluble- fraction was dilluted with sample buffer $(0.055 \mathrm{M}$ Tris- $\mathrm{HCl}, \mathrm{pH} 6.8,2 \%$ SDS, 7\% glycerol, $4.3 \% \beta$-mercaptoethanol, $0.0025 \%$ bromophenol blue) in the ratio of 1:9. Water-soluble fraction was adjusted to $\mathrm{pH} 4.6$ (with $0.1 \mathrm{M} \mathrm{HCl}$ or $0.1 \mathrm{M} \mathrm{NaOH}$ ), filtered through $0.45 \mu \mathrm{m}$ filter (Waters, USA). Clear solution of 4.6-soluble fraction was dilluted with sample buffer in ratio of 1:3. Unsoluble fraction was extracted in $1 \mathrm{~mL}$ of sample buffer $(0.055 \mathrm{M}$ Tris- $\mathrm{HCl}$, pH 6.8, $2 \%$ SDS, $7 \%$ glycerol, $5 \% \beta$-mercaptoethanol, $8 \%$ urea $0.0025 \%$ bromophenol blue) for one hour in ultra sound bath and centrifuged for $15 \mathrm{~min}$ at $16.000 \mathrm{x}$ g. Supernatant was dilluted with sample buffer in ratio of 1:5.

\section{Total antioxidant capacity}

The extract of water soluble proteins and insoluble fractions for determination of total antioxidant capacity was prepared according to the same procedure reported in previous section. To further remove any impurities the obtained extract of water soluble proteins was filtered through $0.45 \mu \mathrm{m}$ pore size filter (Millipore, Billerica, MA, USA) and was lyophilized. To remove any residual lipids, the water insoluble fraction was treated with $\mathrm{n}$-hexane for one hour, filtered through Whatman No.1, dried at room temperature overnight and lyophilized.

The total antioxidant capacity of these fractions was measured based on the QUENCHER method described by Serpen et al. (2008) using $7 \mathrm{mM}$ aqueous solution of ABTS (2,2-azino-bis/3ethil-benothiazoline-6-sulfonic acid) with $2.45 \mathrm{mM}$ $\mathrm{K}_{2} \mathrm{O}_{8} \mathrm{~S}_{2}$ as the stock solution. The working solution of ABTS - + was obtained by diluting the stock solution in water/ethanol (50:50, vol/vol) solution. A ground sample ( $1 \mathrm{mg}$ of water soluble fraction; $6 \mathrm{mg}$ of water insoluble fraction) was mixed with $20 \mathrm{~mL}$ of ABTS $\bullet+$ working solution and the mixture was rigorously shaken for $25 \mathrm{~min}$ in a cold room at 
$4{ }^{\circ} \mathrm{C}$. After centrifugation at $9200 \mathrm{x} \mathrm{g}$ for $5 \mathrm{~min}$ at $10^{\circ} \mathrm{C}$ the absorbance measurement was performed at $734 \mathrm{~nm}$. The total antioxidant capacity was expressed as Trolox equivalent antioxidant capacity (TEAC) in mmol of Trolox per kg of DM.

\section{Statistical analysis}

All measurements were performed in triplicate. Data were subjected to one-way analysis of variance (ANOVA) with IBM-SPSS v20 software and the comparison of means was done by Tuckey's test at $\mathrm{P}<0.05$. In addition, Pearson's correlation was performed to appreciate and interpret interactions between the variables through the linear correlation coefficient. Principal Component Analysis (PCA) (Gaze et al., 2015) was performed using Pearson correlation. Means values of the physicochemical measurements were used. The matrix data set was composed of 6 lines (the samples) and 12 columns (the values of the different analyses). The data were auto scaled before the analysis.

\section{Results and discussion}

\section{Compositional analysis}

Fresh cow milk had a $\mathrm{pH}$ of 6.67 and contained $4.1 \mathrm{~g} / 100 \mathrm{~g}$ of fat, $3.68 \mathrm{~g} / 100 \mathrm{~g}$ of protein and $14.06 \mathrm{~g} / 100 \mathrm{~g}$ of dry matter. The changes detected in gross composition and $\mathrm{pH}$ during ripening of white brined cheese prepared from overheated cow milk are presented in Table 1 .
The composition of fresh cheese indicates that heat treatment used for this investigation significantly affected gross composition of the cheese. Fresh cheese had lower values of DM, but higher TP/DM and F/DM than values of white brined cheeses from pasteurized milk reported by Hayaloglu et al. (2004). The average DM of fresh cheese was $42.39 \mathrm{~g} / 100 \mathrm{~g}$. Higher moisture content of fresh cheese prepared from milk indicated that cheese gel network formed from overheated milk was more hydrophilic than those prepared from pasteurized milk. Such hydrophilic network bounded water tightly and allowed easier diffusion of salt during ripening up to 3.02 (50-days old cheese). Proteolysis had no significant $(\mathrm{P}>0.05)$ influence on $\mathrm{DM}$ throughout 50 days of ripening while the 50 daysripened cheese had $41.97 \mathrm{~g} / 100 \mathrm{~g}$ of DM. However, TP/DM decreased during proteolysis (37.32$32.76 \mathrm{~g} / 100 \mathrm{~g}$, Table 1). Such disagreement could be attributed to the increase of salt content in cheese dry matter. As a result of decrease of TP/DM content, F/DM increased throughout ripening and reached maximum after 50 days $(56.32 \mathrm{~g} / 100 \mathrm{~g}$, Table 1).

The average $\mathrm{pH}$ value of fresh cheese was 6.25. Throughout 50 days of ripening $\mathrm{pH}$ significantly $(\mathrm{P}<0.05)$ decreased down to 4.87. The exceptions were 30- and 40-day old cheeses. Between these samples no significant changes of $\mathrm{pH}$ values were observed. The $\mathrm{pH}$ values obtained at the end of 50 days were slightly higher than values reported for matured (60-90- days old cheeses) East-Mediterranean traditional white brined cheeses prepared from raw and pasteurized cow milk (4.20-4.80;

Table 1. Chemical parameters of white brined cow cheese prepared from overheated milk*

\begin{tabular}{ccccccc}
\hline \multicolumn{7}{c}{ Time of ripening (days) } \\
\hline Parameter & 0 & 10 & 20 & 30 & 40 & 50 \\
\hline $\begin{array}{c}\mathrm{DM} \\
{[\mathrm{g} / 100 \mathrm{~g}]}\end{array}$ & $42.39 \pm 1.21^{\mathrm{a}}$ & $41.30 \pm 0.90^{\mathrm{a}}$ & $39.06 \pm 1.05^{\mathrm{a}}$ & $39.64 \pm 0.65^{\mathrm{a}}$ & $41.04 \pm 1.20^{\mathrm{a}}$ & $41.97 \pm 0.70^{\mathrm{a}}$ \\
\hline $\mathrm{TP} / \mathrm{DM}$ & $37.32 \pm 0.94^{\mathrm{a}}$ & $36.49 \pm 0.52^{\mathrm{a}}$ & $34.46 \pm 1.25^{\mathrm{a}, \mathrm{b}}$ & $33.99 \pm 0.32^{\mathrm{b}}$ & $33.58 \pm 0.68^{\mathrm{b}}$ & $32.76 \pm 0.42^{\mathrm{b}}$ \\
\hline $\begin{array}{c}\mathrm{F} / \mathrm{DM} \\
{[\mathrm{g} / \mathrm{l00} \mathrm{g}]}\end{array}$ & $48.92 \pm 1.02^{\mathrm{c}}$ & $51.16 \pm 1.20^{\mathrm{b}, \mathrm{c}}$ & $53.72 \pm 1.40^{\mathrm{b}}$ & $54.00 \pm 1.30^{\mathrm{b}}$ & $53.86 \pm 0.90^{\mathrm{b}}$ & $56.32 \pm 0.50^{\mathrm{a}}$ \\
\hline $\mathrm{pH}$ & $6.25 \pm 0.03^{\mathrm{a}}$ & $5.49 \pm 0.04^{\mathrm{b}}$ & $5.21 \pm 0.01^{\mathrm{c}}$ & $5.02 \pm 0.02^{\mathrm{d}}$ & $4.98 \pm 0.02^{\mathrm{d}}$ & $4.87 \pm 0.01^{\mathrm{e}}$ \\
\hline $\begin{array}{c}\text { Salt content } \\
{[\mathrm{g} / 100 \mathrm{~g}]}\end{array}$ & $-^{\mathrm{e}}$ & $1.81 \pm 0.05^{\mathrm{d}}$ & $2.41 \pm 0.03^{\mathrm{c}}$ & $2.95 \pm 0.01^{\mathrm{a}}$ & $2.98 \pm 0.04^{\mathrm{a}}$ & $3.02 \pm 0.05^{\mathrm{a}}$ \\
\hline
\end{tabular}

*DM -dry matter content, F/DM - fat in dry matter content; values represent means $\pm \mathrm{SD}$; TP/DM - total protein in dry matter content; values with the same letter whitin the same row are not statistically significant at $\mathrm{P}<0.05$ 
Alichanidis and Polichroniadou, 2008). Relatively slow reduction of $\mathrm{pH}$ of cheese, especially during initial 20 days of ripening, low salt content and high moisture content throughout whole ripening period could considerably affect intensity and the nature of proteolysis. The initial proteolysis in white brined cheese is carried out mainly by residual coagulant (Hayaloglu et al., 2004; Alichanidis and Polichroniadou, 2008). However, conditions registered after initial 20 days of ripening also favored for the activity of plasmins. Thus, it could be expected that plasmin, as heat- stable indigenous enzim of milk which is retained after heating on casein micelles at $\mathrm{pH}$ 4.6-6.6 (Fox et al., 1993), had an important role in primary proteolysis of cheeses.

\section{Total protein, water-soluble, TCA-soluble and PTA-soluble nitrogen}

Variations in the nitrogen fractions of white brined cheese of overheated milk during ripening are shown in Fig 1. The average values of TP/DM and WSN of fresh cheese were $37.32 \mathrm{~g} / 100 \mathrm{~g}$, $2.83 \mathrm{~g} / 100 \mathrm{~g}$, respectively. The largest part of WSN of fresh cheese was TCA-SN whereas fresh cheese contained small amount of PTA-SN. TCA-SN and PTA-SN contents of fresh cheeses was $1.88 \mathrm{~g} / 100 \mathrm{~g}$, $0.1 \mathrm{~g} / 100 \mathrm{~g}$, respectively.

As mentioned, TP/DM decreased throughout ripening and reached minimum after 50 days of ripening (32.76 g/100 g). Such decline of TP/DM content was due to the fact that part of proteolytic products passed into brine (Güven and Karaca, 2001). Given that no significant $(\mathrm{P}<0.05)$ changes between fresh and 10-day old cheeses, as well as between samples ripened for 20-40 days were observed, such decrease could be characterized as slow. However, TP/DM content was very strongly and negatively $(-0.98, \mathrm{P}<0.05)$ correlated with the time of ripening. Similar trend of TP/DM content was observed during ripening of cheeses from pasteurized cow milk by Güven and Karaca (2001).

In percentage terms, during 50 days of ripening protein content of fresh cheese was reduced by $12.22 \%$. Such reduction was much lower (more than twice) than that reported (Guven et al., 2006) for white brined cheese of pasteurized cow milk. This indicated that severe heat-treatment ( $90^{\circ} \mathrm{C}, 10$ minutes), due to strong chemical interactions between serum proteins and caseins, promoted formation of more compact cheese gel matrix than pasteurization which leads to slower proteolysis of cheese prepared from overheated milk and lesser diffusion of low molecular weight products of proteolysis into the brine.

As expected, decrease of TP/DM content throughout ripening was followed by the increase of WSN, TCA-SN and PTA-SN. Soluble nitrogen fractions had almost identical trends during ripening (Fig. 2). WSN content significantly increased during 30 days of ripening and reached maximum of 14.49 g/100 g. Similarly, TCA-SN and PTA-SN increased but up to 40 days. As no starter cultures were used and severe heat treatment of milk was used, the formation of TCA-SN and PTA-SN fractions during ripening could be attributed to the peptidase activity of residual natural microflora (Moatsou et al., 2001). After these periods, probably due to more intensive diffusion of low molecular weight components, there were no significant changes of WSN, TC-SN and PT-SN. Consequently, very strong correlations $(0.91-0.99, \mathrm{P}<0.05)$ between these parameters were registered. Also, strong positive correlations of soluble nitrogen fractions and time of ripening $(0.91-096, \mathrm{P}<0.05)$ and the change of TP/DM were registered. However, the observed values of 50-day old cheese, especially those of WSN contents was lower than usually reported values of different varieties of traditional white brined cow cheeses (Güven and Karaca, 2001; Hayaloglu et al., 2004) and could be characterized as insufficiently matured cheese.

Figure 1. The change of total protein content and different nitrogen fraction during 50 days of ripening of white cow cheese prepared from overheated milk

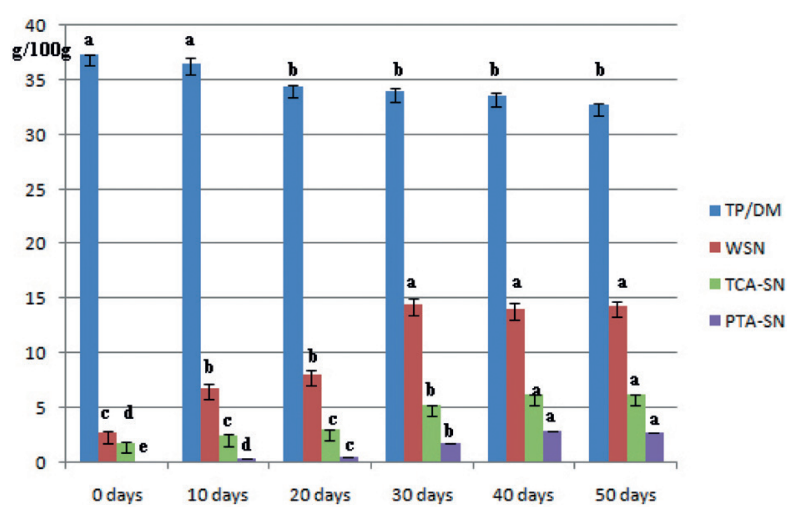

*TP/DM - total protein in dry matter; WSN - water soluble nitrogen; TCA-SN - nitrogen soluble in $12 \%$ TCA; PTA - SN- nitrogen soluble in $5 \%$ PTA 


\section{SDS-PAGE}

SDS-PAGE profiles of Tris- $\mathrm{HCl}$ extracts, water soluble, water insoluble and the $\mathrm{pH}-4.6$ - soluble fractions of fresh and ripened cheeses are shown in Fig.2. It can be seen that overheating induced incorporation of denatured form of the major whey proteins, $\beta$ - Lg and $\alpha$-La, as well as BSA, IgG and lactoferrin. Since intensive bands of these proteins were registered in water insoluble fraction of both fresh and ripened cheeses (Fig.2A), it was obvious that they were tightly incorporated into cheese gel matrix. This was confirmed with the SDS-profile of water soluble proteins of fresh cheese in which only part of BSA and IgG could be noticed (Fig. 2B).

Fraction of $\alpha_{\mathrm{s}}$-caseins $\left(\alpha_{\mathrm{s} 1}-\mathrm{CN}\right.$ and $\left.\alpha_{\mathrm{s} 2}-\mathrm{CN}\right)$ of fresh and ripened cheeses was registered as single band whereas $\beta-\mathrm{CN}$ was detected as two overlapped bands. SDS-PAGE analysis of cheeses clearly showed that both caseins were significantly degraded during whole period of ripening but to the different extent. During 50 days of ripening, residual $\alpha_{\mathrm{s}}$-caseins were degraded extensively up to $15.42 \%$ of initial content. Simultaneously, $\beta-\mathrm{CN}$ degradation progressed much more slowly and the level of unhydrolyzed $\beta$-CN was $76.88 \%$ (Fig. 3). Several authors (Fox et al., 1993; Abd El-Salam et al., 1993; Sarantinopoulos et al., 2002) have highlighted the different resistance of $\alpha_{\mathrm{s}}-\mathrm{CN}$ and $\beta-\mathrm{CN}$ to hydrolysis during the ripening of most cheese varieties. However, the observed values of residual caseins, especially of $\alpha_{\mathrm{s}}-\mathrm{CN}$ were much more lower than those reported for most of matured (60-90-day old cheeses) traditional white brined cheeses (30 \%-40\%- $\alpha_{\mathrm{s}}-\mathrm{CN}$; 85-90\% $\beta-\mathrm{CN}$; Alichanidis and Polychronidau, 2008). Intensive degradation of both major casein fractions could be explained by ripening conditions. The average $\mathrm{pH}$ values of experimental cheeses throughout 30 days were relatively high (6.25-5.02). Also, high and constant moisture content and low salt content in these samples were detected (Table 1). Such conditions obviously favored activity of both, chymosin and plasmin (Fox et al., 1993). As a result of their action already after only 10 days a large number of low molecular peptides with the molecular weight lower than $26 \mathrm{kDa}$ (Fig. 2A) were formed and after 30 days caused an increase in LMW products by more than $100 \%$ (Fig. 3). Most of these products, as confirmed by comparison of SDS-PAGE profiles of Tris- $\mathrm{HCl}$ extracts, water insoluble fractions and water soluble fractions (Fig. 2), remained tightly bounded on the cheese gel matrix. Besides slow growth and activity of residual non-starter bacteria which mostly produced non-protein nitrogen components (Moatsou et al., 2001; Vicente at al., 2000), this can be the main reason of relatively low WSN content and the so-called "specific" ripening.

After 30 days $\alpha_{\mathrm{s}}$-CN continued to break down gradually whereas $\beta$-CN content decreased much more slowly, probably due to inactivation of plasmin at acidic $\mathrm{pH}$. However, the change of residual content of both caseins was in very strong correlation $(-0.97$ and $0.98, \mathrm{P}<0.05)$ with ripening time. As a result of further degradation (during 30-50 days) of caseins, LMW increased, but slower than it could be expected, probably due to further degradation of previously formed products into non-protein compounds (secondary proteolysis). This was consistent with the increase of TCA- and PTA-content (Fig. 1) and supported by very strong negative correlation $(\mathrm{P}<0.05)$ between the changes of residual $\alpha_{\mathrm{s}}-\mathrm{CN}$, $\beta-C N$, LMW and TCA-SN, PTA-SN and WSN content (Table 2). Furthermore, such observation agreed with the change of SDS-profiles of water soluble and $\mathrm{pH}$ 4.6-soluble fractions during 30-50 days of ripening (Fig. 2B). Namely, these fractions were considerably less intensive in 40- and 50-day than in 30- day old cheeses.

It is well known that $\mathrm{p}-\mathrm{k}-\mathrm{CN}$ was resistant to proteolysis (Fox et al., 1993). However, by analyzing SDS-profiles of Tris-HCl extracts and water insoluble fractions of ripened cheeses it was evident that p-k-CN was partially hydrolyzed and detected as two almost overlapped bands. Partial hydrolysis of p-k-CN occurred during initial 10 days of ripening. This was consistent with the model of heat-treated cow micelles proposed by Pesic et al. $(2012,2014)$ in which part of $\mathrm{p}-\mathrm{k}-\mathrm{CN}$ is bounded into complexes and located on the surface of micelles. This makes it accessible to enzymes, probably to plasmin (Trujillo et al., 1998).

Fresh cheese of overheated milk had compact and firm gel network. After water extraction only BSA and IgG were released (Fig. 2B). Proteolysis significantly affected SDS-profiles of water soluble and $\mathrm{pH}$ 4.6- soluble peptides (Fig. 2B). As a result of enzyme acting, after only 10 days, gel network 
became slightly softer and released $\alpha_{\mathrm{s}}-\mathrm{CN}, \beta-\mathrm{CN}$ and LMW products of hydrolysis could be observed. As bands of $\alpha-\mathrm{SN}, \beta-\mathrm{CN}$ were not detected on SDSprofile of 4.6-soluble fraction of 10-day old cheese it could be concluded that were a part of weakly bounded and non-hydrolyzed caseins. Water soluble $\alpha_{\mathrm{s}}-\mathrm{CN}$ disappeared during next 10 days of ripening whereas $\beta-\mathrm{CN}$ has been degraded after 30 days of ripening. In qualitative sense, SDS-profiles of water soluble and 4.6- soluble fractions of 30-50-day old cheese were quite similar although there were some quantitative differences. Both types of profiles of 40- and 50- day old cheese contained less intensive peptides which confirmed the fact that more intensive secondary proteolysis occurred during 40-50 days of ripening.

\section{Total antioxidant capacity of cheese protein fractions}

As evident from previous section, large number of peptides was formed during ripening of cheese prepared from overheated cow's milk. Some of them were water soluble but major part was tightly bounded in cheese gel matrix. Some of these peptides may exert bioactivity including antioxidant activity. Furthermore, secondary proteolysis during

Figure 2. SDS-profiles of Tris- $\mathrm{HCl}$ extracts, water insoluble (A), water soluble and $\mathrm{pH}$ 4.6-soluble protein fractions (B) of cheese prepared from overheated cow milk ripened up to 50 days

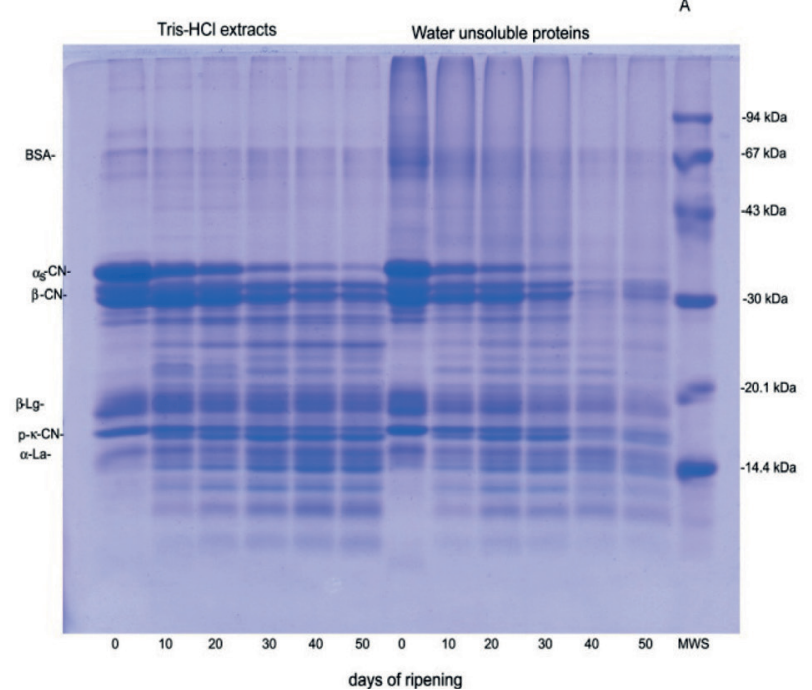

Figure 3. The change (\%) of $\alpha$ s-CN, $\beta-\mathrm{CN}$ and LMWP* during proteolysis of white brined cow cheese

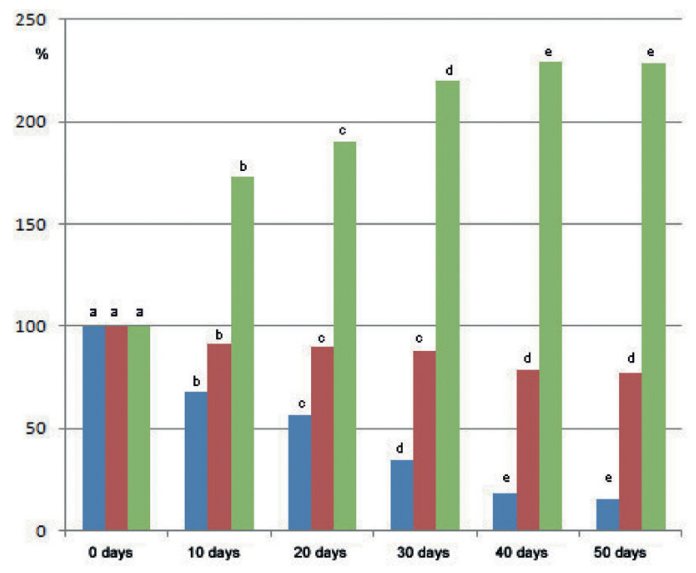

*LMWP-low molecular weight products

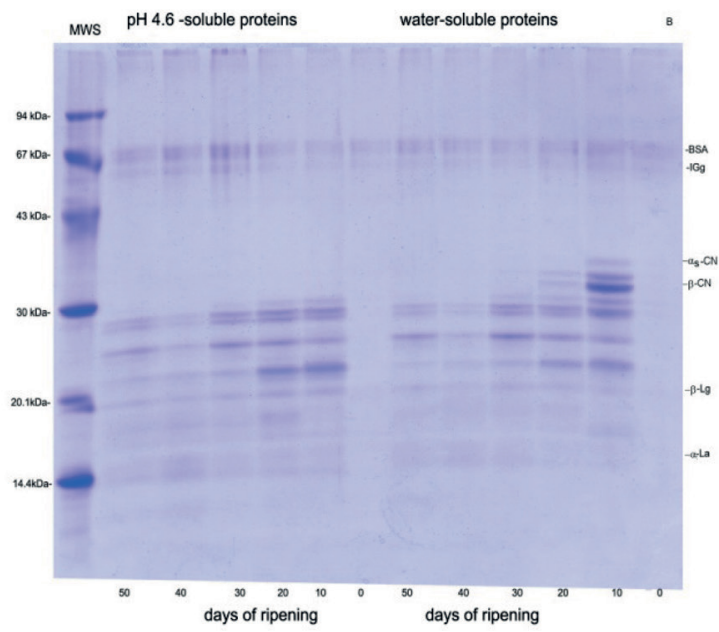

Figure 4. The change of total antioxidant capacity of water soluble protein fraction (AO-WSN) and water insoluble fraction (AO-WIN) during ripening of white brined cow cheese

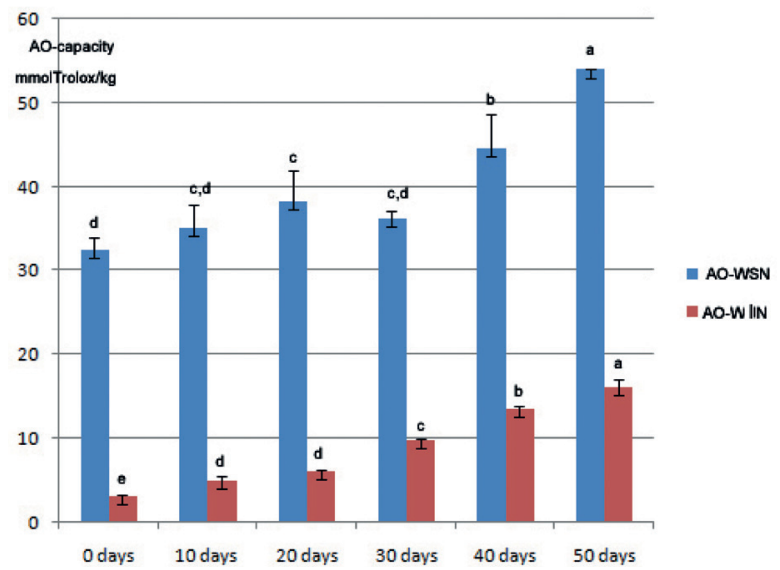


cheese ripening also leads to the formation of other peptides with antioxidant activity (Korhonen and Pihlanto, 2003). In addition, intact caseins and denatured whey proteins also excert antioxidant properties. Due to these facts it can be hypothesized that both, low molecular weight products formed during ripening which are soluble in water and unsoluble fraction which consist of caseins and WP-CN complexes had antioxidant properties. In this investigation total AO-activity of both fractions, water soluble (AO-WSN) and water insoluble fraction (AO-WIN), was measured and presented in Fig. 4.

The average total AO capacity of WSN and WIN fraction of fresh cheese were significantly $(p<0.05)$ different. Total AO-capacity of WSN was more than ten times higher than AO-capacity of WIN (32.53 mmol Trolox/kg, 3.14 mmol Trolox/kg). However, insoluble fraction represents majority of cheese proteins and the antioxidant capacity of this fraction could not be ignored. According to chemical and SDS-PAGE analysis (Figure 1 and 2), the antioxidant properties of water soluble fraction of fresh cheese originate from weakly bounded whey proteins and products of both thermolysis and primary proteolysis. On the other hand, antioxidant capacity of water insoluble fraction encourages from proteins tightly incorporated to complex gel matrix. During ripening total AO-capacity of these fractions increased but with different trends. AO-WSN increased slightly but not significantly (at $\mathrm{P}<0.05$ ) until 30 days of ripening. Then, the average initial AO-WSN increased more intensively, by $37.14 \%$ (40 days ripened cheese) and $66.58 \%$ (50 days ripened cheese). The observed trend was consistant with the change of antioxidant properties of AO-WSN of Cheddar cheese reported by Gupta et al. (2009). By comparing the results of TCA-SN and PTA-SN contents (Table 1) and the SDS-profiles of water soluble fraction it could be noticed that significant increase of AO-WSN started with more intensive secondary proteolysis. This was supported by significant correlation $(0.80, \mathrm{p}<0.05)$ between AO-WSN and WSN content.

Throuhout ripening AO-WIN increased continually and after 50 days reached approximately three times higher average value than the one obtained for fresh cheese. The increase of AO-WIN could be attributed to proteolytic changes which made cheese gel network more able to scavenge free radicals.

Antioxidant capacities of both, water soluble and insoluble protein fractions, of 50 days ripened cheese (matured cheese) were similar or even better than several plant- based protein isolates and hydrolysates which were recognized as products with high antioxidant capacity (Žilic et al., 2012). Therefore, it could be hypothesized that consumption of matured white cow cheese could notably contribute to body's AO defence and prevention of diseases related to oxidative stress. However, further research is needed to elucidate the role of these peptides in the protective functions in human.

Figure 5. Principal component analysis (PCA) of white cow cheese prepared from overheated milk, $\mathrm{PCl} \mathrm{x}$ PC2, of parameters (A) and samples (1-6) (B) as given in Table 1 and Figures 1, 3 and 4
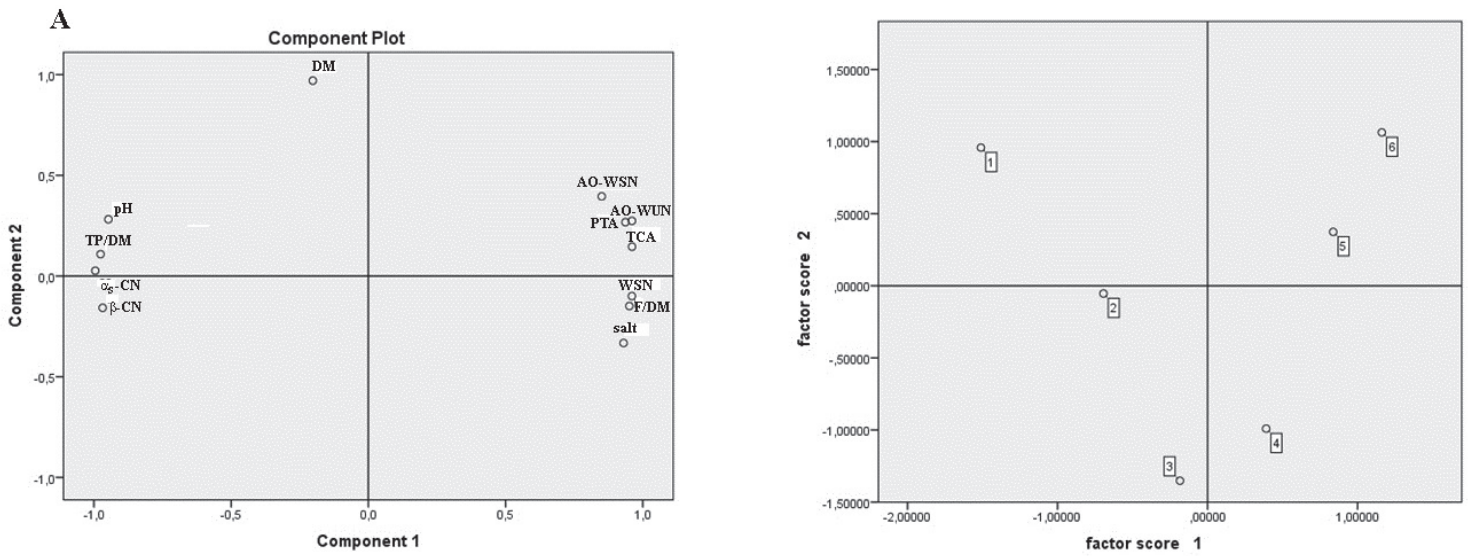

*sample 1 - fresh cheese; samples 2-6-cheeses ripened for 10, 20, 30, 40 and 50 days, respectively 


\section{Principal component analysis}

Fig. 5 (a, b) shows the principal component analysis (PCA) performed with the data gathered from physicochemical analysis of cheese samples. Two main components (PC1 and PC2) were used accounted for $95.68 \%$ of data with a range of $82.97 \%$ and $12.71 \%$ for the first and second component, respectively. $\mathrm{PCl}$ was associated positively with parameters which reflected proteolysis of white brined cheese as WSP, TCA and PTA as well as with antioxidant capacities of both fractions. It was also negatively associated with total amount of proteins in cheese (TP/DM), as well as with the content of major caseins $(\beta-\mathrm{CN}$ and $\alpha-\mathrm{CN})$. Furthermore, based on close grouping, it was evident that WSN, TCA, PTA, AO-WSN and AO-WIN showed association with each other. Similar association was observed between contents of $\mathrm{a}_{\mathrm{s}}-\mathrm{CN}, \beta-\mathrm{CN}$ and $\mathrm{pH}$ of cheeses. Thus, it could be predicted that WSP, TCA, PTA AO-WSN and AO-WIN will positively influence antioxidative capacity of whole cheese, by exerting positive influence on depended component $\mathrm{PCl}$. It could also be predicted that TP/DM, $\mathrm{pH}$ and content of $\alpha_{\mathrm{s}}-\mathrm{CN}$ and $\beta-\mathrm{CN}$ will have negative influence on antioxidant capacity of cheese by exerting negative influence of PC1. PC2 highlighted influence of DM. Through these two components, it is possible to separate the samples into three groups. Samples 4, 5 and 6 (30-50 days ripened cheeses) are allocated on the positive quadrant of $\mathrm{PCl}$, identified by most of characteristics related to the parameters of proteolysis. The negative quadrant of $\mathrm{PCl}$ generated a second group consisting of samples 1 and 2 (fresh and 10 days ripened cheeses) highly influenced by high values of parameters related to fresh cheese $\left(\mathrm{pH}\right.$, total protein content, $\mathrm{a}_{\mathrm{s}}-\mathrm{CN}$ and $\beta-\mathrm{CN}$ content). PC2 generated the third group which consisted only of sample 3 (20 days ripened cheese) influenced by low DM content.

Parameters such as WSN, TCA and PTA are usually used to characterized maturity of cheeses. Given that, based on the results of PCA analyses it could be predicted that white brined cow cheeses with higher values of theese parameters had favorable antioxidant capacities.

\section{Conclusions}

The obtained results clearly showed that severe heat-treatment $\left(90{ }^{\circ} \mathrm{C}, 10 \mathrm{~min}\right)$ induced specific proteolysis of white brined cow cheese. This was a consequence of high content of denatured whey proteins incorporated into cheese gel matrix as well as different nature of cheese gel matrix. Such specificity was reflected through low level of soluble nitrogen fractions, the intensive and continual decrease of $\alpha_{\mathrm{s}}$-caseins, slow degradation of $\beta$-casein throughout whole ripening period and high level of proteolytic products tightly bounded into gel matrix. The investigated fraction had significantly $(\mathrm{P}<0.05)$ different total antioxidant capacity and different trends during ripening. Proteolysis induced the increase of total antioxidant capacity of both, water soluble and water unsoluble fractions. The obtained results also showed that both, content and nature of nitrogen components were essential for the antioxidant capacity.

\section{Acknowledgement}

This work was supported by the Serbian Ministry of Education, Science and Technological Development.

\section{Proteinski profili i ukupni antioksidativni kapacitet $u$ vodi topljivih $i$ netopljivih proteinskih frakcija bijelog sira $u$ salamuri u različitim fazama zrenja}

\section{Sažetak}

U ovom se radu razmatra proteoliza i ukupni antioksidativni kapacitet proteina bijelog sira u salamuri pripremljenog od pregrijanog $\left(90{ }^{\circ} \mathrm{C}, 10\right.$ minuta $)$ kravljeg mlijeka. U bijelim sirevima od pregrijanog kravljeg mlijeka odvijaju se specifične proteolitičke promjene tijekom proteolize, što je posljedica velike količine proteina sirutke inkorporiranih u matricu sira. Specifičnost se odražava kroz relativno nisku razinu topljivih dušičnih frakcija, intenzivan i kontinuiran pad $\alpha_{\mathrm{s}}$-kazeina do $15.42 \%$ inicijalne količine, spore degradacije $\beta$-kazeina tijekom promatranog razdoblja zrenja i veliki sadržaj produkata proteolize koji su čvrsto vezani u proteinsku matricu. 
Uočena je jaka negativna korelacija $(-0,97,-0,98$ and $-0,91 ; \mathrm{p}<0,05)$ između vremena zrenja i rezidualnog $\alpha_{\mathrm{s}}$-kazeina, $\beta$-kazeina i niskomolekularnih produkata. Proteoliza također utječe na ukupni antioksidativni kapacitet i $\mathrm{u}$ vodi topljive $\mathrm{i} \mathrm{u}$ vodi netopljive proteinske frakcije ali $u$ različitom stupnju. Uočen je $i$ različit trend njihove promjene. Ukupni antioksidativni kapacitet $\mathrm{u}$ vodi netopljive frakcije povećava se sporo tijekom cijelog promatranog razdoblja zrenja, dok značajno poboljšanje ukupnog antioksidativnog kapaciteta $\mathrm{u}$ vodi topljive frakcije započinje nakon 30 dana zrenja. Ova saznanja mogu biti korisna za bolje razumijevanje i kontrolu proizvodnje kravljeg bijelog sira u salamuri.

Ključne riječi: pregrijavanje, bijeli kravlji sir, proteoliza, antioksidativni kapacitet

\section{References}

1. Abd El-Salam, M.H., Alichanidis, E., Zerfiridis, G.K. (1993). Domiati and Feta Type cheeses. In P. F. Fox (Ed.), Cheese: Chemistry, physics and microbiology (2nd ed.). Major cheese groups, Vol. 2 (pp. 301-335). London: Chapman \& Hall. doi: 10.1007/978-1-4615-2648-3_11

2. Alichanidis, E., Polichroniday, A. (2008): Characteristics of major taditional regional cheese varieties of East M-Mediteranean countries: A review, Dairy Sci.Tech. 88, 495-510. doi: 10.1051/dst:2008023

3. AOAC (1999): Official methods of analysis. Method 88.05. CH 4, p 13, Gaithersburg, Md: AOAC International.

4. Ardö, Y., Polychroniadou, A. (1999): Laboratory Manual for Chemical Analysis of Cheese, 1-144. Office for Official Publications of the European Communities, Luxembourg.

5. Barać, M.B., Smiljanić, M., Pešić, M.B., Stanojević, S.P., Jovanović, S.T., Maćej, O.D. (2013): Primary proteolysis of white brined goat cheese monitored by high molarity Tris buffer SDS- PAGE system, Mljekarstvo 63, 122-131.

6. Benfeldt, C., Sořensen, J. (2001): Heat treatment of cheese milk: effect on proteolysis during cheese ripening, International Dairy Journal 7, 567-574. doi: 10.1016/S0958-6946(01)00078-4

7. Considine, T., Patel, H.A., Anema, S.G., Singh,H., Creamer, L.K. (2007): Interactions of milk proteins during heat and high hydrostatic pressure treatments - A Review, Innovative Food Science and Emerging Technologies 8, 1-23. doi: 10.1016/j.ifset.2006.08.003
8. Chevalier, F.O., Hirtz, C., Sommerer, N., Kelly, A.L. (2009): Use of reducing/nonreducing two-dimensional electrophoresis for the study of disulfide-mediated interactions between proteins in raw and heated bovine milk, Journal of Agricultural and Food Chemistry 57, 5948-5955. doi: $10.1021 /$ jf900518n

9. Corrêa, A.P.F., Daroit, D.J., Coelho, J., Meira, S.M., Lopes, F.C., Segalin, J., Risso, P.H., Brandelli, A. (2011): Antioxidant, antihypertensive and antimicrobial properties of ovine milk caseinate hydrolyzed with a microbial protease, Journal of Agricultural and Food Chemistry 91, 2247-2254. doi: 10.1002/jsfa.4446

10. Çekiç, S.D., Demir, A., Başkan, K.S., Tütem, E., Apak, R. (2015): Determination of total antioxidant capacity of milk by CUPRAC and ABTS methods with separate characterisation of milk protein fractions, Journal of Dairy Research 82, 177-184. doi: 10.1017/S0022029915000114

11. Diaz, M., Dunn, C.M., McClements, D.J., Decker, E.A. (2003): Use of caseinophosphopeptides as natural antioxidants in oil-in-water emulsions, Journal of Agricultural and Food Chemistry 5, 2365-2370. doi: $10.1021 /$ jf0259841

12. Elias, R.J., Kellerby, S.S., Decker, E.A. (2008): Antioxidant activity of proteins and peptides, Critical Reviews in Food Science and Nutrition 48, 430-441. doi: 10.1080/10408390701425615

13. Fling, S.P., Gregerson, D.S. (1986): Peptide and protein molecular weight determination by electrophoresis using a high-molarity tris- buffer system without urea, Analytical Biochemistry 155, 83-88. doi: 10.1016/0003-2697(86)90228-9

14. Fox, P.F., Law, J., McSweeny, P.L.H., Wallace, J. (1993): Cheese: chemistry, physics and microbiology, Vol.1, Chapman \& Hall, London, UK, 389-438. doi: 10.1007/978-1-4615-2650-6_10

15. Gaze, L.V., Costa, M.P., Monteiro, M.L.G., Lavorato, J.A.A., Conte Júnior, C.A. Raices, R.S.L., Cruz, A.G., Freitas, M.Q. (2015): Freitas Dulce de Leche, a typical product of Latin America: Characterisation by physicochemical, optical and instrumental methods, Food Chemistry 169, 471-477. doi: 10.1016/j.foodchem.2014.08.017

16. Gupta, A., Mann, B., Kumar, R., Sangwan, R. (2009): Antioxidant activity of Cheddar cheeses at different stages of ripening, International Journal of Dairy Technology 62, 339-347. doi: 10.1111/j.1471-0307.2009.00509.x

17. Güven, M., Karaca, O.B. (2001): Proteolysis levels of white cheeses salted and ripened in brines prepared from various salts, International Journal of Dairy Technology 54 (1), 29-33. doi: 10.1046/j.1471-0307.2001.00003.x

18. Güven, M. Yerlikaya, S., Hayaloglu, A. A. (2006): Influence of salt concentration on the characteristics of Beyaz cheese, a Turkish white-brined cheese, Lait 86, 73-81. doi: 10.1051/lait:2005043 
19. Hayaloglu, A., Guven, M., Fox, P.F.J., Hannon, A., McSweeney, P.L.H (2004): Proteolysis in Turkish White-brined cheese made with defined strains of Lactococcus, International Dairy Journal 14, 599-610. doi: 10.1016/j.idairyj.2003.12.008

20. IDF (1982). Determination of the Total solids Content (Cheese and Processed Cheese), Brussels, Belgium: IDF Standard 4A, International Dairy Federation.

21. Korhonen, H., Pihlanto-Leppala, A. (2003): Food-derived bioactive peptides: Opportunities for designing future foods, Current Pharmaceutical Design 9, 1297-1308. doi: 10.2174/1381612033454892

22. Korhonen, H., Pihlanto, A. (2006): Bioactive peptides: Production and functionality-A review, International Dairy Journal 16, 945-960. doi: 10.1016/j.idairyj.2005.10.012

23. Kuchroo, C.N., Fox, P.F. (1982). Soluble nitrogen in Cheddar cheese: comparison of extraction procedures, Milchwissenschaft 37, 331-335.

24. Kumar, S., Teotia, U.V.S., Sanghi, A. (2013): Antioxidative property of cow milk caseinates hydrolyzed with different proteases, International Journal of Pharmacy and Pharmaceutical Sciences 5, 418-422.

25. Maćej, O., Jovanović, S., Barać, M. (2007): Milk proteins. Pp 223-256. Faculty of Agriculture, Belgrade.

26. Moatsou, G., Kandarakis, I., Moscopoulou, E., Anifantakis, E., Alichanidis, E. (2001): Effect of technological parameters on the characteristic of kasseri cheese made from raw or pasteurised ewe's milk, International Journal of Dairy Technology 54, 69-77. doi: 10.1046/j.1471-0307.2001.00010.x

27. Möller, N.P., Scholz-Ahrens, K.E., Roos, N., Schrezenmeir, J. (2008): Bioactive peptides and proteins from foods: Indication for health effects, European Journal of Nutrition 47(4), 171-182. doi: 10.1007/s00394-008-0710-2

28. Parrella, A., Caterino, E., Cangiano, M., Criscuolo, E., Russo, E., Lavorgna, M., Isidori, M. (2012): Antioxidant properties of different milk fermented with lactic acid bacteria and yeast, International Journal of Food Science and Technology 47, 2493-2502. doi: 10.1111/j.1365-2621.2012.03127.x

29. Pattom,S.,Hongsprabhas, P.(2013): Effectofcoagulantson antioxidant capacity of milk protein curds and their tryptic hydrolysates, Journal of Food Biochemistry 37, 203-211. doi: 10.1111/j.1745-4514.2011.00625.x

30. Pesic, M.B., Barac, M.B., Stanojevic, S.P., Ristic, N.M., Macej, O.D., Vrvic, M.M. (2012): Heat induced casein-whey protein interactions at natural $\mathrm{pH}$ of milk: A comparison between caprine and bovine milk, Small Ruminant Research 108 (1-3), 77-86. doi: 10.1016/j.smallrumres.2012.06.013

31. Pesic, M.B., Barac, M.B., Stanojevic, S.P., Vrvic, M.M. (2014): Effect of $\mathrm{pH}$ on heat-induced casein-whey protein interactions: A comparison between caprine milk and bovine milk, International Dairy Journal 39 (1), 178-183. doi: 10.1016/j.idairyj.2014.06.006
32. Power, O., Jakeman, P., FitzGerald, R.J. (2013): Antioxidative peptides: enzymatic production, in vitro and in vivo antioxidant activity and potential applications of milk-derived antioxidative peptides, Amino Acids 44, 797-820. doi: 10.1007/s00726-012-1393-9

33. Rival, S.G., Fornaroli, S., Boeriu, C.G., Wichers, H.J. (2001): Caseins and casein hydrolysates. 1. Lipoxygenase inhibitory properties, Journal of Agricultural and Food Chemistry 49, 287-294. doi: 10.1021/jf000392t

34. Sarantinopoulos, P., Kalantzopoulos, G., Tsakalidou, E. (2002): Effect of Enterococcus faecium on microbiological, physicochemical andsensory characteristics of Greek Feta cheese, International Journal of Food Microbiology 76, 93-105. doi: 10.1016/S0168-1605(02)00021-1

35. Serpen, A., Gökmen, V., Pellegrini, N., Fogliano, V. (2008): Direct measurement of the total antioxidant capacity of cereal products, Journal of Cereal Science 48, 816-820. doi: 10.1016/j.jcs.2008.06.002

36. Smiljanić, M., Pesic, M., Stanojevic, S., Barać, M. (2014): Primary proteolysis of white brined cheese prepared from raw cow milk monitored by high-molarity Tris buffer SDS-PAGE system, Mljekarstvo 64, 102-110.

37. Trujillo, A.J., Guamis, B., Carretero, C. (1998): Hydrolysis of Bovine and Caprine Caseins by Rennet and Plasmin in Model Systems, Journal of Agricultural and Food Chemistry 46, 3066-3072. doi: $10.1021 /$ jf9802272

38. Trujillo, A.J., Buffa, M., Casals, I., Fernández, P., Guamis, B. (2002): Proteolysis in goat cheese made from raw, pasteurized or pressure-treated milk, Innovative Food Science and Emerging Technologies 3 (4), 309-319. doi: 10.1016/S1466-8564(02)00056-5

39. Vasbinder, A.J., de Kruif, C.G. (2003): Caseinwhey protein interactions in heated milk: the influence of pH. International Dairy Journal 13, 669-677. doi: 10.1016/S0958-6946(03)00120-1

40. Vicente, M.S., Ibanez, F.C., Barcina, Y.R., Barron, L.J.R. (2000): Casein breakdown during ripening of Idiazabal cheese: Influence of starter andrennet type, Journal of the Science of Food and Agriculture 81, 210-215. doi: $\quad$ 1002/1097-0010(20010115)81:2<210::AIDJSFA803>3.0.CO;2-B

41. Zulueta, A., Maurizi, A., Frigola, A., Esteve, M.J., Coli, R., Burini,G. (2009): Antioxidant capacity of cow milk, whey and deproteinized milk, International Dairy Journal 19, 380-385. doi: 10.1016/j.idairyj.2009.02.003

42. Žilić, S., Akıllıŏlu, G. Serpen, A., Barać, M., Gökmen, V. (2012): Effects of isolation, enzymatic hydrolysis, heating, hydratation and Maillard reaction on the antioxidant capacity of cereal and legume proteins, Food Research International 49, 1-6. doi: 10.1016/j.foodres.2012.06.031

43. Yates, Z., Gunasekaran, K., Zhou, H., Hu, Z., Liu, Z., Ketchem, R.R. (2010): Histidine residue mediates radical-induced hinge cleavage of human IgG1, The Journal of Biological Chemistry 285, 18662-18671. doi: 10.1074/jbc.M1 10.108597 